\title{
Клінічний випадок лікування інфікованої рани стегна з ураженням синтетичного судинного протеза
}

\begin{abstract}
Мета роботи: дослідження клінічного випадку ускладненої інфікованої післяопераційної рани стегна у хворого після реконструкції дистального анастомозу біфуркаційного алопротеза та аналіз результатів їі лікування із застосуванням ВАКтерапії.

У статті представлено клінічний випадок інфікованої рани стегна у хворого після реконструкції псевдоаневризми дистального анастомозу через три роки після біфуркаційного аорто-стегнового протезування. Стратегія лікування ускладненої післяопераційної рани полягала у поєднанні системної антибіотикотерапії із локальною вакуум-асистованою терапією рани. На підставі результатів посіву вмісту рани на патогенну мікрофлору із визначенням чутливості до антибіотиків було верифіковано збудники та підібрану цільову антибактеріальну терапію. Локальний клінічний ефект вакуум-асистованої терапії виявлявся в адекватному дренуванні вмісту ускладненої інфікованої рани. Застосування даного лікувального комплексу в описаного пацієнта дозволило досягти позитивної динаміки інфекції ділянки хірургічного втручання із остаточною ліквідацією інфекційного осередку через сім тижнів. Вищезгадане комбіноване лікування є ефективним комплексним способом загоєння післяопераційної рани. Віддалене спостереження пацієнта протягом шести місяців підтвердило відсутність інфекції рани та ознак псевдоаневризми.
\end{abstract}

Ключові слова: інфікована рана стегна; синтетичний судинний протез; реконструктивні операційні втручання.

На сьогодні у світі спостерігається суттєве зростання поширеності критичної ішемії нижніх кінцівок (КІНК). В Україні, за даними різних авторів, летальність внаслідок КІНК коливається від 8,9 до 25 \% [1, 2]. КІНК, як термінальний прояв патології периферичних артерій нижніх кінцівок, $€$ абсолютним показанням до хірургічного лікування із проведенням реваскуляризації. Остання дозволяє зберегти кінцівку та значно покращити якість життя хворого. Однак, незважаючи на успіхи реконструктивних операцій на судинах нижніх кінцівок, розвиток інфекції ділянки хірургічного втручання (ІДХВ) може значно погіршувати їх результати. Ускладнення у вигляді інфікування ділянки операційного доступу спостерігається у 4-25 \% прооперованих пацієнтів [6]. Лікування інфікованої післяопераційної рани значно збільшує термін перебування пацієнта у стаціонаpi. Особливо небезпечним є поширення інфекції у глибину рани та ураження судинної реконструкції, що може призвести арозивної кровотечі, втрати кінцівки або смерті [2].

Метою роботи було дослідження клінічного випадку ускладненої інфікованої післяопераційної рани стегна у хворого після реконструкції анастомозу з приводу псевдоаневризми дистального анастомозу біфуркаційного алопротеза та аналіз результатів ії̈ лікування із застосуванням ВАК-терапії.

Клінічний випадок. Пацієнт С., 1948 р. н., звернувся на консультацію до судинного хірурга 11 грудня 2015 р. $з$ приводу появи пульсуючого утво- ру в правій паховій ділянці, болю в ділянці утвору, особливо при підвищенні артеріального тиску. 3 анамнезу відомо, що у 2012 р. пацієнту було проведено імплантацію біфуркаційного аорто-стегнового протеза з приводу синдрому Леріша. Післяопераційний період перебігав без особливостей. Рани загоїлись первинним натягом. Біль у спокої регресував. Хворому було рекомендовано періодичний огляд судинного хірурга.

На момент огляду 11.12.2015 р. встановлено діагноз: “Атеросклероз. Синдром Леріша. Стан після біфуркаційного аорто-стегнового протезування (2012р.). Псевдоаневризма дистального анастомозу справа”. Хворий госпіталізований у відділення судинної хірургії ЛОКЛ для дообстеження та лікування. Проведено дуплексне сканування аорти, протеза та обох стегново-підколінних сегментів. Протокол УЗД: Біфуркаційний протез функціонує, кровотік по браншах протеза магістральний. Справа бранша протеза без патологічних включень та рідини навколо. У місці дистального анастомозу псевдоаневризма 5х6 см. Глибока артерія стегна прохідна, поверхнева стегнова артерія оклюзована від початку. Зліва бранша біфуркаційного протеза та дистальний анастомоз без особливостей. Глибока артерія стегна прохідна, поверхнева стегнова артерія оклюзована від початку.

Після проведення доопераційних загальноклінічних лабораторних та інструментальних обстежень пацієнту виконано хірургічне втручан- 
ня: резекцію псевдоаневризми дистального анастомозу біфуркаційного аорто-стегнового протеза справа, реконструкцію дистального анастомозу (14.12.2015). Протокол операції. На 1 см вище пупартової зв’язки, заочеревинно виділено праву браншу біфуркаційного протеза із задовільним пульсуючим кровотоком, взято на турнікет. У верхній третині стегна дистальніше псевдоаневризми 3 латерального доступу виділено глибоку артерію стегна, остання атеросклеротично змінена, прохідна. Доступ поширено у краніальному напрямку. Після гепаринізації перетиснено браншу біфуркаційного протеза. Псевдоаневризмотомія, видалено тромбомаси з чашки, виявлено дефект анастомозу по латеральній поверхні. Висічено анастомоз, мобілізовано браншу протеза та проксимальну частину глибокої артерії стегна. Вшито сегмент протеза-вставки в кінець бранші протеза та в кінець глибокої артерії стегна. Проведено запуск кровотоку, гемостаз та накладено шви на рану. У ранньому післяопераційному періоді виникла нагноєна серома в ділянці рани верхньої третини стегна. Розкрито післяопераційну рану в ділянці інфекції м’яких тканин, евакуйовано гнійний вміст, проведено некректомію нежиттєздатних тканин, під час якої на дні рани виявлено протез (рис. 1).

Виконано посів вмісту рани на патогенну флору та визначено чутливість до антибіотикотерапії. Тактика лікування пацієнта полягала в антибіотикотерапії широкого спектра дії, а місцево - ВАК-терапії.

У матеріалі, що надійшов на мікробіологічне дослідження, було виявлено E. Coli. Відповідно до антибіотикочутливості збудник був чутливим до таких антибіотиків: тобраміцин 23 мм (чутл.), амікацин 22 мм (чутл.), іміпенем 23 мм (чутл.), тайгецил 23 мм (чутл.), гатифлоксацин 20 мм (помірно чутл.).

Призначено консервативне лікування із цільовою антибіотикотерапією. Пацієнт отримував антибіотикотерапію сумарно впродовж 70 днів такими середниками: піперациліну тазобактам 4,5 г

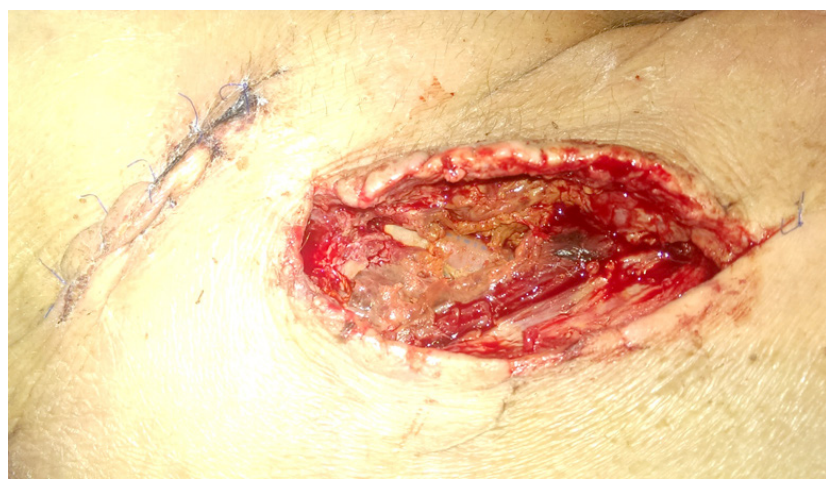

Рис. 1. Некректомія нежиттєздатних тканин. Виявлення протеза на дні рани.
3 рази на добу (6 днів), гатифлоксацин - 200 мг 2 рази на добу (14 днів), цефоперазон+сульбактам 2 г 2 рази на добу (7 днів), іміпенем 1 г 3 рази на добу (8 днів), ванкоміцин 1 г 2 рази на добу (12 днів), піперациліну тазобактам 4,5 г 3 рази на добу (12 днів), ципрофлоксацин 500 мг 2 рази на добу (11 днів). Паралельно пацієнт отримував протигрибкову терапію, профілактику дисбактеріозу та суміш бензатину бензилпеніциліну стерильного та бензилпеніциліну новокаїнову сіль (Біцилін-5) відповідно до протоколу. Курс ВАК-терапії передбачав зміну пов’язки кожні 3 дні. Рана верхньої третини стегна відгукнулась на визначену тактику лікування. Через 24 дні від початку терапії рана майже повністю очистилась та помітно гранулювала (рис. 2). Через 5 тижнів лікування імплант повністю вкрився грануляційною тканиною з ознаками епітелізації від країв рани (рис. 3). Через 7 тижнів відбулось повне загоєння вторинним натягом ускладненої рани верхньої третини стегна (рис. 4). Хворо-

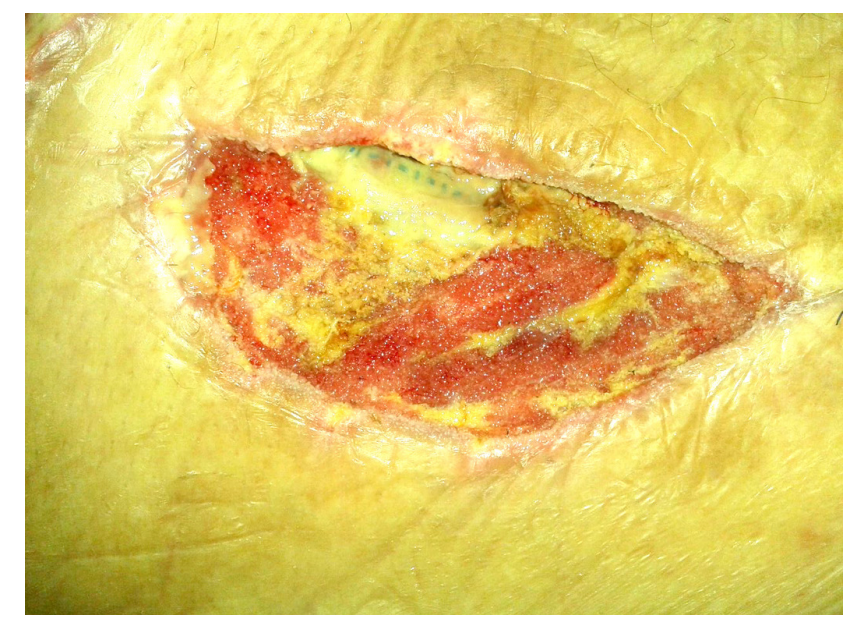

Рис. 2. Майже повне очищення та помітна грануляція рани.

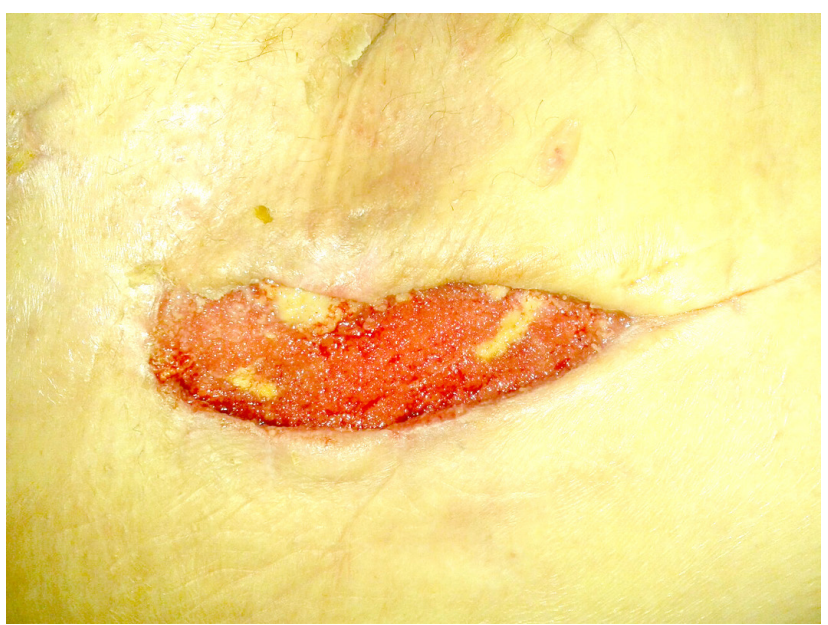

Рис. 3. Через 5 тижнів лікування: імплант повністю вкрився грануляційною тканиною з ознаками епітелізації. 


\section{ПОВІДОМЛЕННЯ}

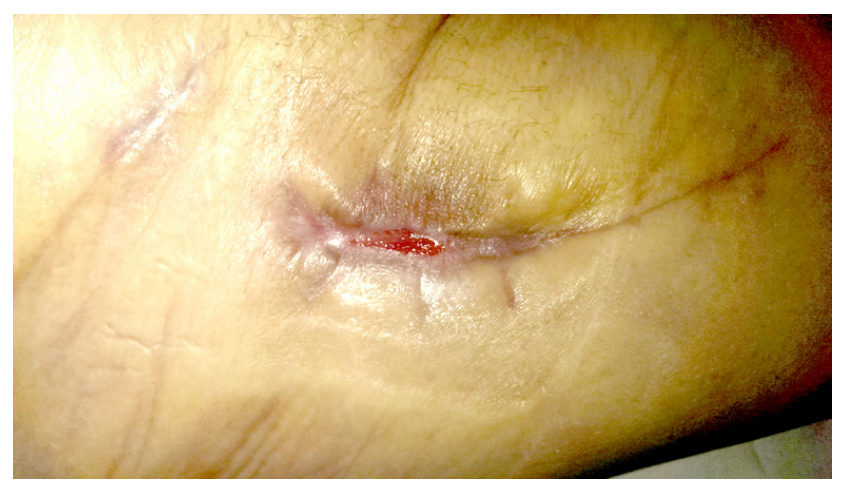

Рис. 4. Повне загоєння вторинним натягом ускладненої рани верхньої третини стегна.

го було повторно оглянуто через 6 місяців, ознак повторної інфекції рани, псевдоаневризми не виявлено. На даний час пацієнт перебуває під спостереженням.

Обговорення. Розвиток ІДХВ у пацієнта із функціонуючим судинним протезом може стати причиною фатальної арозивної кровотечі [4]. Традиційна місцева терапія рани є малоефективною [5]. Основним методом лікування інфікованої рани із ураженням імпланта $є$ операційне втручання: видалення біфуркаційного протеза та аутове-

\section{СПИСОК ЛІТЕРАТУРИ}

1. Chronic critical limb ischemia / A. Dohmen, S. Eder, W. Euringer [et al.] // Dtsch. Arztebl. Int. - Vol. 109 (6). - P. 95101. doi: 10.3238/arztebl.2012.0095

2. Greenblatt D. Y. Predictors of surgical site infection after open lower extremity revascularization / D. Y. Greenblatt, V. Rajamanickam, M. W. Mell // Journal of Vascular Surgery. - 2011. - Vol. 54. - P. 433-439. doi: 10.1016/j.jvs.2011.01.034

3. Treatment of aortic prosthesis infections by graft removal and in situ replacement with autologous femoral veins and fascial strengthening / I. Heinola, I. Kantonen, M. Jaroma [et al.] // European Journal of Vascular and Endovascular Surgery. - 2016. - Vol. 51(2). - P. 232-239. Retrieved from http://dx.doi. org/10.1016/j.ejvs.2015.09.015

4. Hsu-Tang Chenga. Efficacy and safety of negative pressure

\section{REFERENS}

1. Dohmen, A., Eder, S., Euringer, W. (2012). Chronic Critical Limb Ischemia. Dtsch. Arztebl. Int., 109 (6), 95-101. doi: 10.3238/arztebl.2012.0095

2. Greenblatt, D.Y., Rajamanickam, V., \& Mell, M.W. (2011). Predictors of surgical site infection after open lower extremity revascularization. Journal of Vascular Surgery, 54, 433-439. doi: 10.1016/j.jvs.2011.01.034

3. Heinola, I., Kantonen, I., Jaroma, M., Albäck, A., Vicatmaa, P., Aho, P., \& Venermo, M. (2016). Treatment of aortic prosthesis infections by graft removal and in situ replacement with autologous femoral veins and fascial strengthening. European Journal of Vascular and Endovascular Surgery, 51(2), 232-239. Retrieved from http://dx.doi.org/10.1016/j.ejvs.2015.09.015

4. Hsu-Tang Chenga, Yung-Chang Hsu, \& Chao-I Wu. (2014). нозного репротезування стегновими венами [3]. Цей метод $є$ більш травматичним та може супроводжуватися рядом ускладнень самої повторної реконструкції [4]. Тому як метод місцевого лікування ІДХВ у даного пацієнта було запропоновано використати ВАК-терапію післяопераційної ускладненої рани, що рекомендована відповідно до сучасних протоколів догляду за ранами [5].

Консервативне лікування інфікованої рани стегна із ураженням судинного імпланта з використанням ВАК-терапії дало можливість уникнути травматичної операції із високим ризиком розвитку тяжких ускладнень.

Наше спостереження підтверджує роботи ряду дослідників [2, 5, 6], що розглядають локальну ВАК-терапію як ефективну альтернативу лікування ІДХВ.

Висновки. 1. У пацієнтів після реконструктивних операційних втручань з приводу КІНК поширеним ускладненням $€$ ІДХВ, що може спричити фатальну арозивну кровотечу.

2. Сучасним ефективним методом місцевого лікування ІДХВ з ураженням алопротеза $є$ ВАКтерапія післяопераційної ускладненої рани, що підтвердив даний клінічний випадок.

wound therapy for Szilagyi grade III peripheral vascular graft infection / Hsu-Tang Chenga, Yung-Chang Hsu, Chao-I Wu // Interactive CardioVascular and Thoracic Surgery. - 2014. Vol. 19. - P. 1048-1052. doi:10.1093/icvts/ivu289

5. Negative pressure incision management system in prevention of groin wound infection in vascular surgery patients / Jan H. Koetje, Karsten D. Ottink, Iris Feenstra, Wilbert M. Fritsch // Surgery Research and Practice. - 2015. - P. 791-795. doi: $10.1155 / 2015 / 303560$

6. Factors associated with surgical site infection after lower extremity bypass in the Society for Vascular Surgery (SVS) Vascular Quality Initiative (VQI) / J. A. Kalish, A. Farber, K. Homa [et al.] // Journal of Vascular Surgery. - 2012. - Vol. 60 (5). P. 1238-1246. doi: 10.1016/j.jvs.2014.05.012

Efficacy and safety of negative pressure wound therapy for Szilagyi grade III peripheral vascular graft infection. Interactive Cardio Vascular and Thoracic Surgery, 19, 1048-1052. doi:10.1093/icvts/ivu289

5. Jan H. Koetje, Karsten D. Ottink, Iris Feenstra, \& Wilbert M. Fritschy. (2015). Negative pressure incision management system in prevention of groin wound infection in vascular surgery patients. Surgery Research and Practice, 791-795. doi: $10.1155 / 2015 / 303560$

6. Kalish J. A., Farber A., Homa K., Trinidad M., Beck A., Davies M.G., Kraiss L.W. et al. (2012). Factors associated with surgical site infection after lower extremity bypass in the Society for Vascular Surgery (SVS) Vascular Quality Initiative (VQI). Journal of Vascular Surgery, 60 (5), 1238-1246. doi: 10.1016/j.jvs.2014.05.012 
T. I. VYKHTYUK ${ }^{1}$, YU. H. OREL ${ }^{1}$, B. M. GAVRYLIV², YU. Z. KHORKAVYY ${ }^{1}$

Danylo Halitskyi Lviv National Medical University ${ }^{1}$

Lviv Regional Clinical Hospital ${ }^{2}$

\section{CLINICAL CASE OF TREATMENT OF INFECTED WOUND IN THE GROIN WITH VASCULAR GRAFT AFFECTION}

The aim of the work: to learn the clinical case of complicated infected postoperative wound of patient's thigh after the reconstruction of the distal anastomosis of bifurcation alloprosthesis and analyze the results of treatment with V.A.C. therapy.

The article presents the clinical case of infected wound of patient's thigh after reconstruction of distal anastomotic pseudoaneurysm three years after the aorto- bifemoral graft placement. Approach to treatment of complicated postoperative wound combined systemic antibiotic therapy with local vacuum-assisted wound therapy. The pathogens and selected targeted antibiotic therapy was verified on the basis of wound culture results for pathogenic microflora with sensitivity to antibiotics. Local clinical effect of vacuum-assisted therapy was detected in adequate drainage of content of complicated infected wound. The use of such combination therapy for the given patient enabled to achieve positive dynamics of surgical site infection with complete elimination of the nidus of infection in seven weeks. The abovementioned combination therapy is an effective comprehensive approach to healing postoperative wounds. Long-term follow-up of the patient for six months confirmed the absence of wound infection and signs of pseudoaneurysm.

Key words: infectious hip wound; syntetic vessel prothesis; reconstructive surgical treatment.

Т. И. ВИХТЮКํำ Ю. Г. ОРЕЛ 1 , Б. М. ГАВРИЛОВ², Ю. З. ХОРКАВЫЙ

Львовский национальный медицинский университет имени Данила Галицкого ${ }^{1}$ Львовская областная клиническая больница ${ }^{2}$

\section{КЛИНИЧЕСКИЙ С.УУЧЙ .ЕЧЕНИЯ ИНФИЦИРОВАННОЙ РАНЫ БЕДРА С ПОРАЖЕНИЕМ СИНТЕТИЧЕСКОГО СОСУДИСТОГО ПРОТЕЗА}

Цель работы: исследование клинического случая осложненной инфицированной послеоперационной раны бедра у больного после реконструкции дистального анастомоза бифуркационного аллопротеза и анализ результатов ее лечения с применением ВАК-терапии.

В статье представлен клинический случай инфицированной раны бедра у больного после реконструкции псевдоаневризмы дистального анастомоза через три года после бифуркационного аорто-бедренного протезирования. Стратегия лечения осложненной послеоперационной раны заключалась в сочетании системной антибиотикотерапии с локальной вакуум-ассистированной терапией раны. На основании результатов посева содержимого раны на патогенную микрофлору с определением чувствительности к антибиотикам были верифицированы возбудители и подобрана целевая антибактериальная терапия. Локальный клинический эффект вакуум-ассистированной терапии оказывался в адекватном дренировании содержания осложненной инфицированной раны. Применение данного лечебного комплекса в описанного пациента позволило достичь положительной динамики инфекции области хирургического вмешательства с окончательной ликвидацией инфекционного очага через семь недель. Вышеупомянутое комбинированное лечение является эффективным комплексным способом заживления послеоперационной раны. Отдаленное наблюдение пациента в течение шести месяцев подтвердило отсутствие инфекции раны и признаков псевдоаневризмы.

Ключевые слова: инфицированная рана бедра; синтетический сосудистый протез; реконструктивные операционные вмешательства. 